\title{
Management of Hydropower Tunnels to Prevent Collapse and Remedial Measures
}

Sein Win Tun and Sunil Kumar Singal

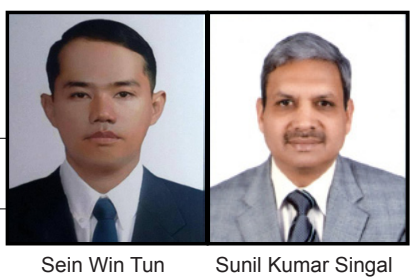

Abstract: Tunnels are important structures in hydropower projects as they reduce the length of the water conductor system. However, tunnels also pose the possibility of collapse during construction which may cause significant time and cost overruns. Moreover, collapsing tunnels pose threats to workers and machinery. Systematic control and understanding of tunnel physics is key to preventing these dangers. In this paper, we explore the most effective means for constructing tunnels for hydropower projects.

Keywords: Hydropower tunnels, tunnel collapse, construction management

\section{Introduction}

Tunnels are very important for developing hydro-

1 power as they provide various appurtenant underground structures in hydropower projects such as power tunnels, river diversion during construction of dams, tunnels for grouting and inspection of dams, service tunnels, gate shafts, surge chambers, underground powerhouses, free flow water conveyance tunnels, and spillway tunnels. However, during tunnel construction, these structure occasionally collapse because of geological conditions, lack of proper management and careless mistakes made during construction. In most cases, tunnel engineers can predict whether a tunnel will collapse or not during the next excavation circle based on geological conditions and probe drilling data at the open tunnel face. More often than not, tunnels collapse because tunnel engineers prioritize expense and time over safety as extra support works such as pipe-poling, umbrella fore-poling and pre-grouting, are very costly and time-consuming. However, nothing is as important as safety in tunnels. Therefore, the necessary arrangements and techniques have to be managed to avoid potential human and project harm.

Tunnel collapse can be differentiated in three portions based on where the collapse takes place:

- At or around the tunnel portal,

- Along the finished length of the tunnel, and

- At the tunnel face or crown portion.

Ground stabilization techniques are most effective to prevent collapse. They are as follows:

- Regular inspection of the tunnel portal and tunnel interior;

- Probe-drilling at each segment;

- Fore-poling, pipe-poling (up to $5 \mathrm{~m}$ ), and long pipepoling (5 10 m);

- Multiple rift or ring cutting methods control blasting and scaling by experienced skilled labor;

- Rock-bolting, wire-mesh, shotcreting and steel arch supporting,

- Installation of drainage pipes to lower ground water, and

- Grouting.

\section{Literature Review}

In this study, a detailed literature review has been undertaken on the types of tunnel collapse, the causes of these collapses, and the possible remedial measures (Table 1).

Based on the above literature review, tunnel collapses occur in one of three places along the tunnel. Those locations and the potential causes of collapse in those areas are summarized in Figure 1.

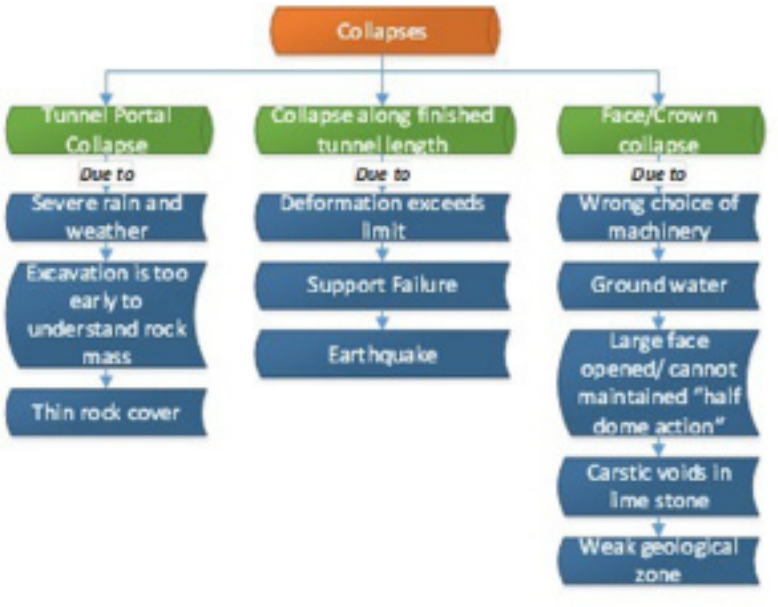

Figure 1: Major portions with types and causes of collapse

\section{Prevention of Tunnel Collapses and Remedial} Measures

To prevent and mitigate tunnel collapse, the following measures need to be conducted along with the application of ground stabilization techniques.

\section{- Regular Inspection of the Tunnel Portal and Tunnel Interior}

To prevent collapse at the portal and along the finished tunnel portion, regular inspections should be carried out.

If the tunnel portal or any place along the tunnel collapses, all personnel working inside the tunnel could be seriously injured. Therefore, regular inspection for abnormal conditions at the portal, and throughout the tunnel must be carried out, and immediate remedial actions undertaken:

(a) Ground survey: leveling must be checked regularly to insure proper support for the tunnel,

(b) Convergence measurements and deformation tests must be conducted inside the tunnel and suspected cracked areas must be strengthened with extra 


\begin{tabular}{|c|c|c|c|}
\hline $\begin{array}{l}\text { Ref } \\
\text { No. }\end{array}$ & Types of Collapse & Causes of collapse & Remedial measures \\
\hline 1. & $\begin{array}{l}\text { (i) Collapse at } \\
\text { Jointed and faulted sections. } \\
\text { (ii) Surface settlement } \\
\text { and deformation along the } \\
\text { alignment }\end{array}$ & $\begin{array}{l}\text { Wrong selection of tunnel boring machines } \\
\text { (TBM) due to insufficient geological investigation } \\
\text { during bidding stage. }\end{array}$ & $\begin{array}{l}\text { Replace by Shielded Road Header instead } \\
\text { of TBM. }\end{array}$ \\
\hline 2. & Face Collapse & $\begin{array}{l}\text { Presence of sandy with clay layer, in upper het- } \\
\text { erogeneous and lower homogeneous type above } \\
\text { the tunnel face and ground water. }\end{array}$ & $\begin{array}{l}\text { Longer fore-piles and lowering ground } \\
\text { water. }\end{array}$ \\
\hline 3. & $\begin{array}{l}\text { Collapse of tunnel portal } \\
\text { slope }\end{array}$ & $\begin{array}{l}\text { Due to severe rain storm and abnormal } \\
\text { weather. }\end{array}$ & $\begin{array}{l}\text { Continuous maintenance is executed in } \\
\text { accordance with danger classes. }\end{array}$ \\
\hline \multirow[t]{9}{*}{4.} & $\begin{array}{l}\text { Face collapse and portal } \\
\text { collapse }\end{array}$ & $\begin{array}{l}\text { Due to instability (that cannot be maintained } \\
\text { "half dome action"). }\end{array}$ & $\begin{array}{l}\text { Excavation is carried out multi stage } \\
\text { instead of full face. }\end{array}$ \\
\hline & $\begin{array}{l}\text { Tunnel portal, Overall mass } \\
\text { slide }\end{array}$ & \multirow{8}{*}{$\begin{array}{l}\text { (a) Rock masses are highly discontinuous and } \\
\text { low quality due to weathering } \\
\text { (b) Excavation effects the stability of natural or } \\
\text { man-made slope } \\
\text { (c) At portal regions, in situ stresses } \\
\text { may be highly non-uniform } \\
\text { (d) Over-break is high due to poor quality rock } \\
\text { (e) Seismic } \\
\text { (f) Portal excavation is too early to understand } \\
\text { about the rock mass. }\end{array}$} & \multirow{8}{*}{$\begin{array}{l}\text { Umbrella arch method, diaphragm of piles, } \\
\text { stability and reinforcement techniques of } \\
\text { rock slopes. }\end{array}$} \\
\hline & Upper slope slide & & \\
\hline & Outer rib slide & & \\
\hline & $\begin{array}{l}\text { Upper slope subsidence/ } \\
\text { collapse }\end{array}$ & & \\
\hline & Crown face over-break & & \\
\hline & Internal crown/rib failure & & \\
\hline & Invert failure & & \\
\hline & Seal rupture & & \\
\hline 5. & $\begin{array}{l}\text { Various tunnel collapse } \\
\text { pattern }\end{array}$ & $\begin{array}{l}\text { Condition of shear zone, discontinuity condi- } \\
\text { tions nearby shear zone, geometry of joint with } \\
\text { tunnel, water inflow, face condition, excavation } \\
\text { method, the effect of configuration in earth, rock } \\
\text { mass structure, rock mass classification, rock } \\
\text { type, overburden, tunnel depth, tunnel geom- } \\
\text { etry, RQD, joint condition and joint spacing. }\end{array}$ & $\begin{array}{l}\text { Developed prediction module for potential } \\
\text { tunnel face failure, using the data obtained } \\
\text { from } 20 \text { sites in Korea, with the help of } \\
\text { GIS-based intelligent management system, } \\
\text { named (Intelligent Tunnel Information Sys- } \\
\text { tem). }\end{array}$ \\
\hline 6. & Face collapse & Excessive over-break & $\begin{array}{l}\text { Initial strength and stiffness of shotcrete } \\
\text { linings. }\end{array}$ \\
\hline 7. & $\begin{array}{l}\text { Collapse at tunnel face and } \\
\text { shaft }\end{array}$ & $\begin{array}{l}\text { Water inflow is too high, and also draw- } \\
\text { down due to head difference ( } 3 \sim 5 \mathrm{~m}) \\
\text { which can cause blow-out and collapse. }\end{array}$ & Prevent the water inflow by grouting. \\
\hline 8. & $\begin{array}{l}\text { Cave-in occurred during tun- } \\
\text { neling under a caustic void, } \\
\text { creating crater }\end{array}$ & Difficult to define & $\begin{array}{l}\text { Stiff support system, steel sets, pre-rein- } \\
\text { forcement, by pre-investigation of probe } \\
\text { drilling. }\end{array}$ \\
\hline 9. & Huge collapse & Deformation exceeds the limit & Systematic rock-bolting. \\
\hline 10. & $\begin{array}{l}\text { Roof settlement, displace- } \\
\text { ment converged }\end{array}$ & Support failure & $\begin{array}{l}\text { Backfill to avoid collapse of settlement area, } \\
\text { and stiff support was installed. }\end{array}$ \\
\hline 11. & Portal collapse & Thin rock cover & $\begin{array}{l}\text { Jet grouting, and supporting by reinforced } \\
\text { concrete. }\end{array}$ \\
\hline 12. & $\begin{array}{l}\text { (1) Collapse during enlarge- } \\
\text { ment of pilot tunnel } \\
\text { (2) Tunnel deformation, Set- } \\
\text { tlement of crown and con- } \\
\text { vergence. }\end{array}$ & Loosing of the ground & $\begin{array}{l}\text { Long and middle span fore-piling tech- } \\
\text { niques. }\end{array}$ \\
\hline
\end{tabular}




\begin{tabular}{|c|c|c|c|}
\hline 13. & Crown collapse & Loosening zone & Long fore-poling \\
\hline 14. & Top heading collapse & Geological faults zone & Jet grouting \\
\hline 15. & Collapse of $400 \mathrm{~m}$ long section & $\begin{array}{l}\text { The main causes of seismically induced failures } \\
\text { in tunnels are liquefaction, fault rupture and } \\
\text { strong seismic shaking. }\end{array}$ & $\begin{array}{l}\text { For a proper seismic design, both the } \\
\text { strength and flexibility of the tunnel should } \\
\text { be considered. }\end{array}$ \\
\hline 16. & Complete Collapse & $\begin{array}{l}\text { Following the earthquake; concrete crushing, } \\
\text { shear cracking and offset displacement of the } \\
\text { lower footing }\end{array}$ & $\begin{array}{l}\text { Higher design earthquake resistance ( } 2000 \\
\text { year return period). }\end{array}$ \\
\hline 17. & Tunnel-arch collapse & $\begin{array}{l}\text { Construction without the ground stabilization } \\
\text { method }\end{array}$ & Ground stabilizing method. \\
\hline 18. & $\begin{array}{l}\text { Face instability, displace- } \\
\text { ment above roof }\end{array}$ & Shallow overburden & $\begin{array}{l}\text { Engineering Record and checking engineer } \\
\text { within safety management. }\end{array}$ \\
\hline 19. & $\begin{array}{l}\text { Cave-in/collapse incident, } \\
\text { buried or trapped the work- } \\
\text { force }\end{array}$ & - not mentioned & $\begin{array}{l}\text { shielded drives (segments, } \\
\text { pipe-jacking) with pre-cast lining. } \\
\text { A threat posed to the excavation crew To } \\
\text { secure the roof in advance by means of } \\
\text { suitable measures (e.g. reinforcement mat- } \\
\text { ting and anchors) in order to protect the } \\
\text { head. }\end{array}$ \\
\hline 20. & $\begin{array}{l}\text { Face and crown immediate } \\
\text { collapse }\end{array}$ & Brittle fracture zone & Long face reinforcing method \\
\hline 21. & $\begin{array}{l}\text { Large deformation and col- } \\
\text { lapse }\end{array}$ & $\begin{array}{l}\text { Weakness zone such as heavily jointed and } \\
\text { faulted zone }\end{array}$ & Convergence analysis \\
\hline
\end{tabular}

Table 1: Types and Causes of Tunnel Collapse with Remedial Measures.

supports immediately. The deformation can be tested with strain gauges, or by manual measurements with steel measuring tape, or precise surveying, and/or

(c) Drainage weep-hole pipes must be installed immediately in areas where underground water is accumulating, causing overload stress on the tunnel.

\section{- Preparing for the most Terrible Situation by Installing Quality Steel Pipes of Air and Water Supply}

If collapse occurs behind the working face, it is extremely important to supply air, water and nutrients to persons possibly trapped inside. At normal working condition, air and water supply pipes are used for drilling and other tunnel works. These same pipes can be used to supply water, air and nutrients to personnel while working to access the trapped area. These supply pipes must be 75 to $100 \mathrm{~mm}$ diameter quality steel pipes as illustrated (Figure 2). This type of accident occurred earlier this year in Bhutan at the Punatsangchu Hydropower Project. Six people died ("http://www. kuenselonline.com/six-men-buried-alive-inside-p-iichamber/."[22]).

In the case of an emergency, communication with those trapped inside is vital. Therefore, all workers must have two-way radios and safety equipment, such as torch helmets, safety shoes, reflective wear, safety glass goggles, and dust masks. Quality electric cables should also be used inside the tunnel for reliable electric supply in any condition.

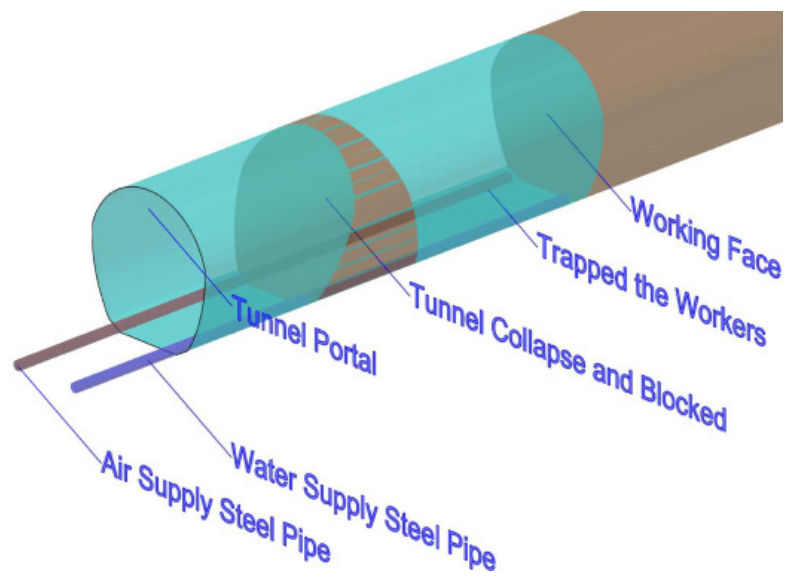

Figure 2: Tunnel collapse behind the working face.

\section{- Checking by "Probe Drilling" in Every Circle}

This type of check is done to prevent face collapses and crown collapses. Probe-holes are drilled to forecast geological conditions, rock quality, water leakage, and rock class [23]. Generally, tunnel collapses occur in the crown portion. Therefore, in every circle, the rock condition of 3 to $4 \mathrm{~m}$ ahead of the tunnel is estimated by "probe-drilling" on the periphery of crown portion. The forecast of ahead conditions is achieved by evaluating the color of rock powder or flush water, recording the penetration per minute, noting the sound of drilling, and observing the quantity of water coming out from the aquifer strata. It is an easy, accurate and inexpensive method to foresee tunnel conditions for the next excavation circle. 


\section{- Pre-supports}

To avoid crown collapses, pre-supports should be provided. There are two primary styles of pre-supports.

- Umbrella fore-poling is aimed at limiting the decompression in the crown immediately ahead of the face. In this type of pre-support, longitudinal bars are installed ahead of the tunnel from the periphery of the face, typically over the upper third or quarter of the excavated profile (Figure 3) [24].

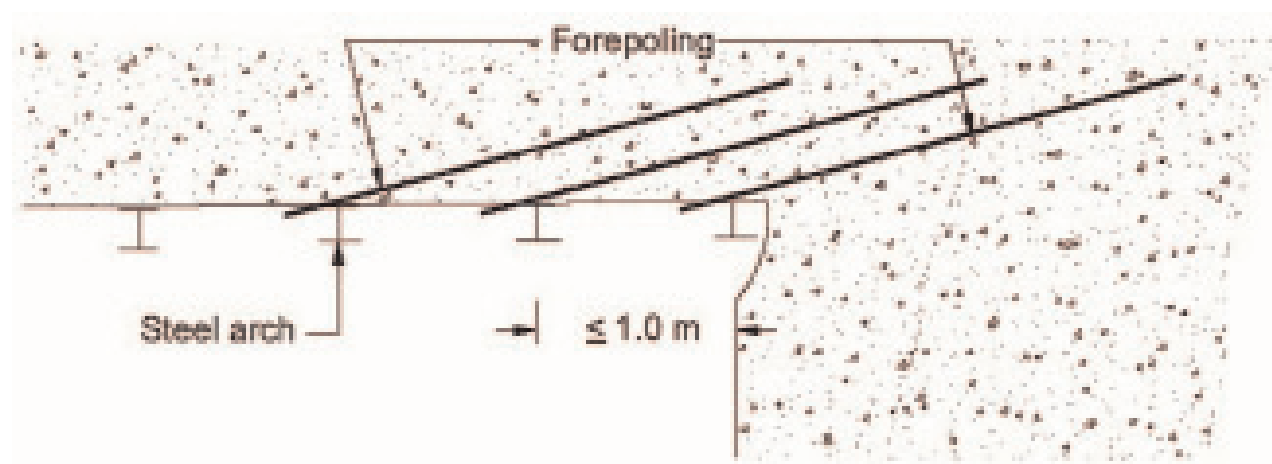

care to prevent falling rock (Figure 5 and 6) [25][26].

\section{- Rock-bolting, Wire-mesh, Shotcreting and Steel Arch Supporting}

These are extra support methods for ground stabilization to prevent collapse. Based on preinvestigation, if the tunnel engineer suspects collapse, then steel arch sets, shortcrete with steel fibres, and wire-mesh are kept to be ready for immediate support. The steel arch set is the strongest and must be prefabricated. A steel arch fabrication workshop is shown in Figure 7.

If after blasting the rock cracks, the rock fragments between these cracks will fall. Gradually, the cracks will become larger and looser and weaker in binding strength, which will exacerbate the collapse. To prevent loose rock

Figure 3: Arrangement of umbrella fore-poling [24].

- Pipe poling is a stronger modified method as combination of fore-poling and pre-grouting. The pipe-poling method is used ahead of the tunnel face for advanced length. But this method is costly and time consuming. Therefore, it is used only in very weak geological zones (Figure 4).

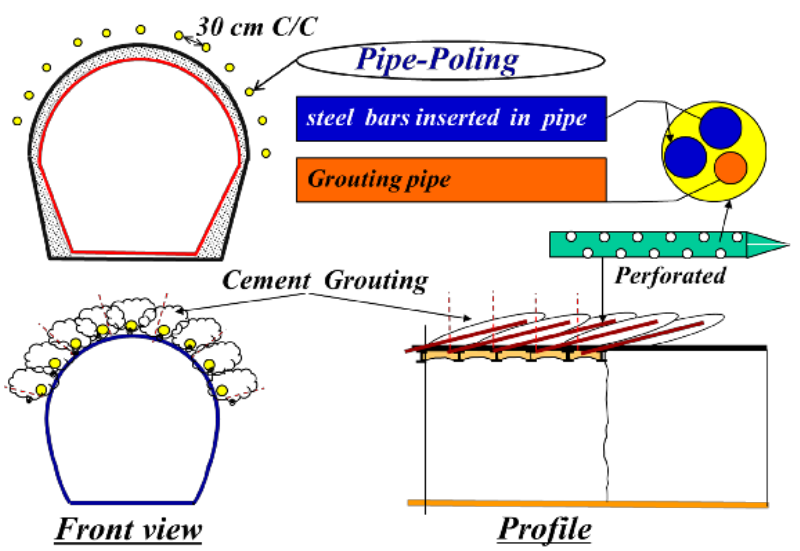

Figure 4: Arrangement of pipe-poling.

\section{- Multiple Drift Cutting Method, Control Blasting and Scaling}

Where the tunnel section is large and geological conditions are very weak, ring cutting or the multiple drift method is found to be the safest method. Even if collapse does occur, ring cutting will not cause severe damage because the centre core is an immediate support for the collapsed area. In ring cutting a large tunnel is divided into upper and lower portions, and benching would follow after heading is done. Since this method is used only in weak geological areas, scaling must be done by experienced skilled labour with great fragments from falling, and to provide immediate early support, shotcreting mixed with steel fibers should be used. These steel fibers will improve the crack resistance capacity and serve as multidirectional reinforcement (Figure 8). To provide stronger reinforced concrete, ready-made wire-mesh should be placed on the affected area just before shotcreting.

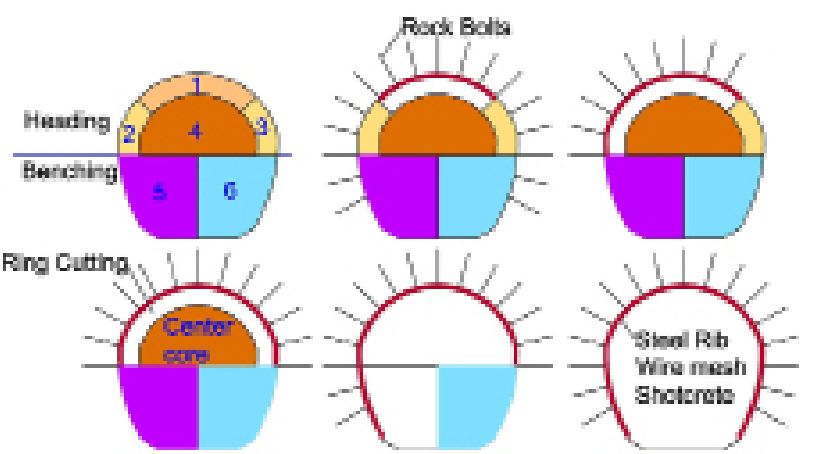

Figure 5: Multiple drift or ring cutting method.

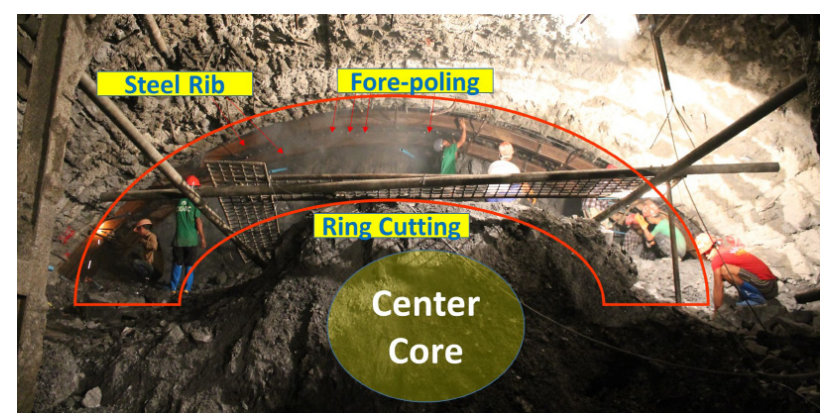

Figure 6: Multiple drift or ring cutting method used at Thahtay HPP in Myanmar. 


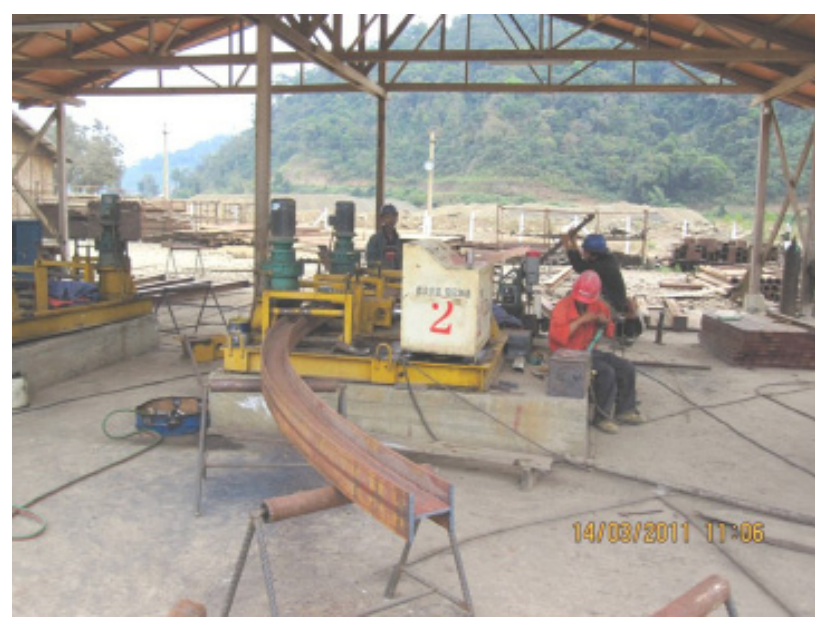

Figure 7: Steel rib fabrication workshop

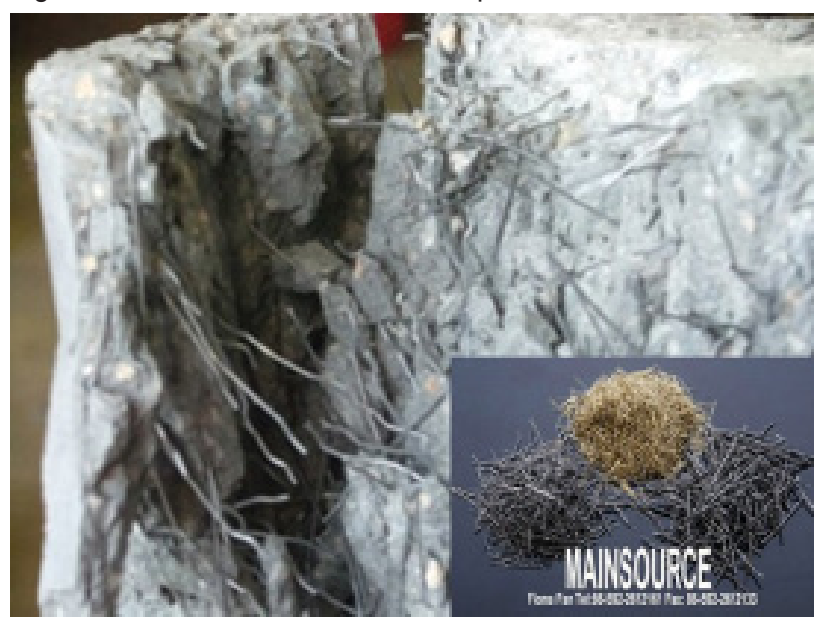

base camp. After shotcreting, shotcrete workers return, and machine operators go back after mucking, and so on. But tunnel collapse can occur at any time. Because of this all skilled workers, machinery, and machine operators must be ready on standby. Of course, this is a difficult thing to demand of workers which is why they need to be satisfied with proper incentives for the work.

Many companies construct temporary buildings near the front of the tunnel where workers can rest and entertain themselves (television, movies, snooker, chess) while on standby. This will help diminish the long-term fatigue that many workers experience during tunneling work.

\section{- Safety}

When a tunnel collapses, the safety of all personnel is the highest importance. Therefore, all workers must be on alert inside the tunnel, and they must be fresh and not overtired. Therefore, they should not work for more than three hours continuously inside the tunnel. A skillful team leader must be on hand to direct action in case of a collapse. Figure 9 illustrates a typical division of labor for a tunneling team.

The safety of the machinery is also important because they are very expensive. Machine operators must be alert and the machine must not be left inside the tunnel, if this can be safely avoided. In weak geological zones, some machinery like a Drilling Jumbo, should not be used if possible.

1) Senior Tunnel Engineer (Team Leader)
Figure 8: Steel fiber shotcrete [27]

\section{- Installation of Drainage Pipes and Lowering Ground Water and Dewatering Facilities}

To prevent crown collapse along the tunnel, installation of weep-hole drainage pipes are important because tunnel collapse primarily occur when water extrudes from the tunnel face. Drainage can prevent over stress due to accumulating ground water, and improve the ground stability. Moreover, shotcrete cannot be applied to the surface while water is coming out from the surface. If perforated weep-hole drainage pipes are inserted, water will drain out and the surface area will dry sooner. For dewatering facilities inside the tunnel, submersible pumps are the most favored piece of equipment.

\section{- Get Ever Ready of Enough Skilled Workers and Machinery}

In tunnel works, experienced labour is key. For example, experienced workers are needed for drilling, shotcrete, and mucking. Generally, tunneling works occurs around the clock. In one tunnel circle, when the drilling work is finished, then drilling workers return to
2) Junior Tunnel

Engineer at Inlet

Tunnel Face

\section{I}

3) Junior Tunnel

Engineer at outlet

Tunnel Face $\Uparrow$

\begin{tabular}{|l|}
\hline 4) Tunnel Surveyor \\
\hline 5) Specialist/Team Leader for Drilling \\
\hline 6) Specialist/Team leader for Blasting \\
\hline 7) Specialist Team Leader for Arc Steel Ribs Fabrication as well as Installation \\
\hline 8) Specialist/Team Leader for Wire mesh \& Shotcreting \\
\hline 9) Specialist/Team Leader for Grouting \\
\hline 10) Team Leader for Formwork and concreting \\
\hline 12) Electrician \\
\hline 13) Team Leader for Water Supply \\
\hline 14) Team Leader for Ventilation, and Air Supply \\
\hline 15) Team Leader for Procurement and Material Production \\
\hline
\end{tabular}

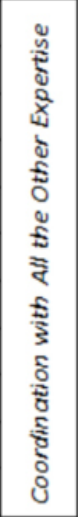

Figure 9: Tunneling team division of labour

\section{- Remedial Measures after Tunnel Surprise}

When tunnel collapse occurs at the crown portion of the tunnel face, the collapsing materials must not be mucked out. If they are mucked out, the collapse will continue (Figure 10) 


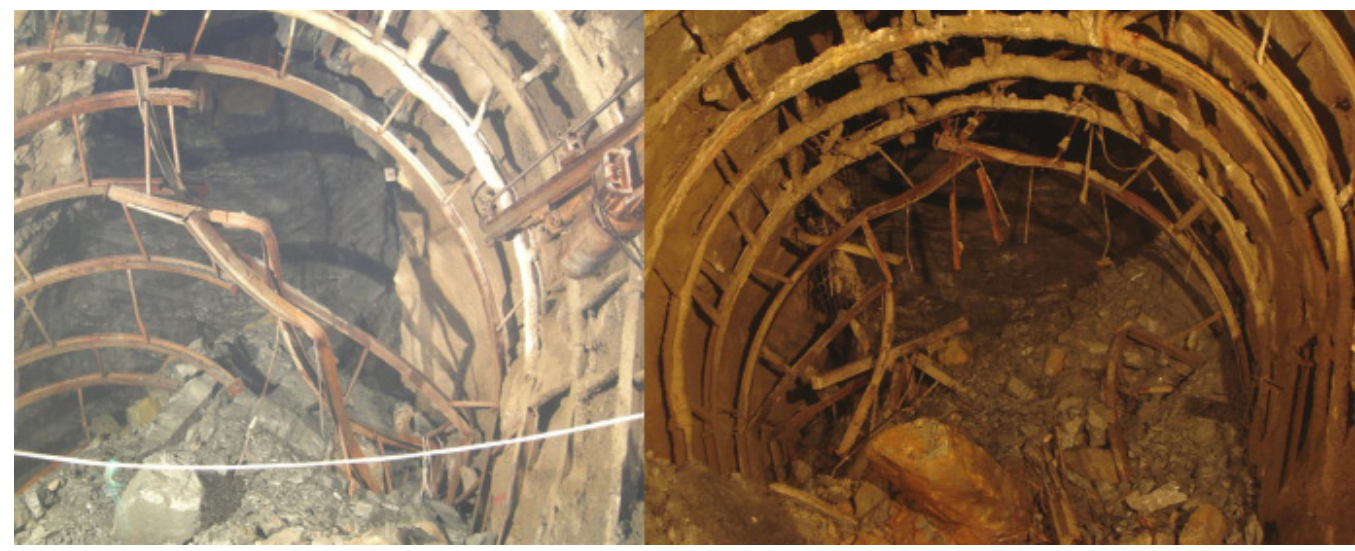

the new alignment.

\section{Conclusions}

In this study, an attempt has been made to review the causes of tunnel collapse and the preventive as well as remedial measures that can be used in the case of tunnel collapse. By following these procedures and

Figure 10: Huge collapse at crown because of mucking out the dropped material [28].

If a tunnel starts to collapse uncontrollably, construction teams must wait until the slope of collapsed material is stable. Rock boulders can be backfilled to block and prevent continuous collapse, so that the collapsed material or backfilled material supports itself and blocks the collapsed hollow itself.

In this condition, drain pipes must be installed in all directions to reduce underground water. The collapse hollow can be back-filled by grouting. After backfill is complete, collapse materials can be mucked out, and forward supports placed ahead of the face by pipepoling combined with pre-grouting. After that, the excavation of the tunnel can safely proceed (Figure 11).

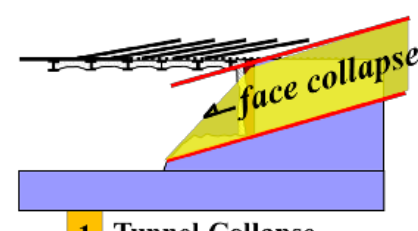

1 Tunnel Collapse

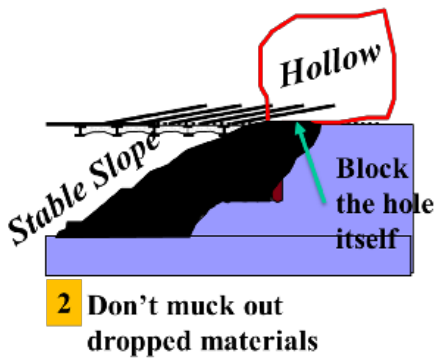

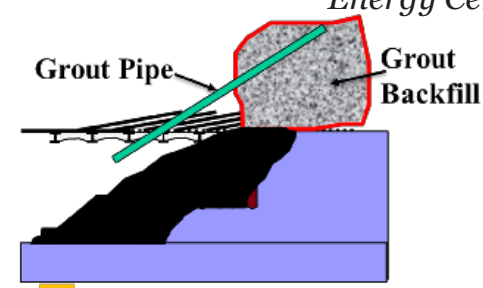

3 Backfill the cavity

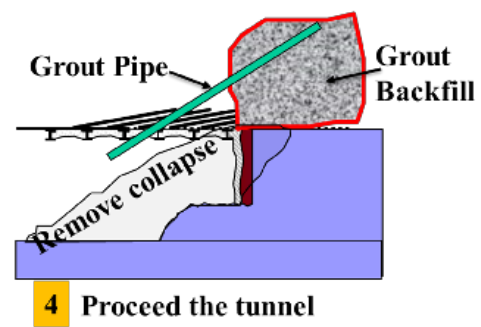

management techniques, severe tunnel collapse can be avoided.

\section{Acknowledgments}

The authors would like to thank Indian Technical and Economic Cooperation (ITEC) programme, Ministry of External Affairs, Govt. of India for sponsoring to carry out Master of Technology in Alternate Hydro Energy Systems at Indian Institute of Technology, Roorkee, India.

Sein Win Tun, M.Tech., Graduated Civil Engineering Student from Yangon Technological University (Myanmar) in 2004. He obtained his M.Tech Degree in Alternate Hydro Energy System from Alternate Hydro Energy Centre (AHEC), Indian Institute of Technology (IIT), Roorkee, India. In 2008, he joined Department of Hydropower Implementation, Ministry of Electricity and Energy, Myanmar where currently he is working as Staff Officer. Mr Tun has experiences in construction and management of large scale hydropower projects for more than six years.

\section{Corresponding E-mail: useinwintun@} gmail.com

Sunil Kumar Singal, $P h D$, graduated in Civil Engineering from University of Roorkee (India) (now Indian Institute of Technology Roorkee) in 1983. He obtained his $M E$ degree in earthquake engineering and a PhD from IIT Roorkee. In 1984 he joined the Alternate Hydro Energy Centre

Figure 11: Procedures for remedial measure after surprise

\section{- The Last Solution for the Most Terrible Tunnel Surprises}

In the most severe collapse situations, deviation from the original alignment should be made to the new one. Although, this type of situation may not happen if the above procedures for remedial measures are followed. To go with the new alignment is only the final solution. After excavating the new alignment of tunnel, the previous collapsed void in old alignment must be backfilled by pressure grouting, because the old alignment, at which the weakestarea exists, is very near to
(AHEC) at the University of Roorkee as Scientist. Currently he is working as Associate Professor in AHEC, IIT Roorkee. Dr. Singal has research, teaching and consultancy experience of more than 32 years in the field of small hydropower.

\section{E-mail: sunilksingal@gmail.com}

\section{References}

1. Dr. M. Cetin Gumusoglu, "Tunnels related to Metro, Highway and Sewerage schemes in Istanbul," 2005.

2. S. Konishi, T. Ono, T. Kitagawa, H. Iida, A. Isogai, and T. Matsunaga, "Effect of ground water on tunnel face stability in the soft ground," 2005. 
3. Y. Baek, O. I. Kwon, H. B. Koo, and G. J. Bae, "Study on state and pattern analysis of tunnel portal slope in Korea," 2005.

4. H. Gercek, "Three-dimensional regions in tunnels," 2005.

5. C.Y. Kim, S. W. Hong, K. Y. Kim, S. H. Baek, G. J. Bae, B. H. Han, and K. S. Jue, "GIS-based application and intelligent management of geotechnical information and construction data in tunnelling," 2005.

6. Young-ZooLee, W. Schubert, and K. Chang-Yong, "The influence of the round length on the stability of tunnel face and unsupported span," 2005.

7. N. Koronakis, P. Kontothanassis, D. Katsaris, and J. Bournazos, "Design of water isolation grouting for reducing high water inflows in urban shallow tunnels," 2005.

8. N. Kazilis \& G. Aggistalis, "Engineering geology and design of primary support of road tunnels. Cases from the Egnatia roadway," 2005.

9. R. Osgoui \& E. Ünal, "Rock reinforcement design for unstable tunnels originally excavated in very poor rock mass," 2005.

10. B. W.-S. \& D. S. W. Wittke, "The $9 \mathrm{~km}$ long Kallidromo tunnel of the new highspeed railway line Athens-Thessaloniki, Greece, tunnel sections in squeezing ground," 2005.

11. M. Vardar, B. Koçak, and H. Karaog `lan, "Tunnel portal problems in landslide areas - Black Sea Highway Project, Turkey," 2005.

12. T. Yamamoto, K. Murakami, and S. Shirasagi, "Application of the tunnel face reinforcement and fore-piling," 2005.

13. S. Tayama, K. Kanzawa, H. Hirano, and S. Isoda, "Tunnel excavation penetrating active landslide area - Second-TOMEI Expressway Inasa No. 2 Tunnel," 2005.

14. A. Da Vià1, M. Marotta1, and G. Peach2, "High pressure jet grouting in tunnels - a case study," 2005.

15. A. Giannakou, P. Nomikos, I. Anastasopoulos, A. Sofianos, G. Gazetas, and P. Yiouta-Mitra, "Seismic behaviour of tunnels in soft soil: parametric numerical study and investigation on the causes of failure of the Bolu tunnel (Düzce, Turkey, 1999),"
2005.

16. M. Ozben, F. Tokgozoglu, and S. Isik, "Seismic assessment results and actual application in the

complex ground conditions of Bolu tunnels after the 1999 Duzce earthquake," 2005.

17. T. Kitagawa, H. Iida, Y. Tadenuma, S. Konishi, T. Ono, and K. Okutsu, "Construction method of shallow railway tunnel in loose sandy ground," 2005.

[18] A. Beil and F. Aïssaoui, "Safety management - Checking Engineer in Conventional Tunnelling," 2005 .

19. M. Bandmann, W. Chromy, and A. Haack, "Prevention of accidents during the tunnel construction phase," 2005.

20.Y. Mitarashi, T. Matsuo, H. Tezuka, T. Tsuji, T. .Haba, and T. Okabe, "Development and application of a long face reinforcing method with GFRP tubes in mountain tunneling," 2005.

21. C. Y. Kim, K. Y. Kim, S. H. Baek, S. W. Hong, G. J. Bae, W. Schubert, K. Grossauer, and Y. Z. Lee, "Tunnel convergence analyses in heterogeneous/ anisotropic rock masses," 2015.

22. "http://www.kuenselonline.com/six-men-buriedalive-inside-p-ii-chamber/." .

23. Anders Östberg, "High Precision Drilling," in Tunnelling in Rock by Drilling and Blasting Spathis \& Gupta (Eds), 2013.

24. D. Chapman, N. Metje, and A. Stärk, "Introduction to Tunnel Construction," 2010, p. 98 100.

25. IS : 5878 (Part II/Sec I) - 1970, "Code of Practivce For Construction of Tunnel Conveying Water, Part II Underground Excavation in Rock, Section I, Drilling and Blasting," 2000.

26.IS : 5878 (Part III) - 1972, "Code of Practive For Construction of Tunnel Conveying Water, Part III, Underground Excavation in Soft Strata," 2000.

27. Steel fibre-reinforced shotcrete, "http://america. pink/steel-fibre-reinforced-shotcrete_4165744. html," 2016.

28.U Maw Thar Htwe, "Tunnelling Practice In Geological Complex Area At Kun Hydropower Project," 2010. 